RESEARCH PAPER

\title{
Standardization of Osmotic Drying Time for Apple Pops and Apple Rings
}

\author{
Babita Sharma* and Devina Vaidya \\ Department of Food Science and Technology, Dr YS Parmar University of Horticulture and Forestry, Nauni, Solan, \\ Himachal Pradesh, India \\ Corresponding author: babitasharma9419@gmail.com
}

Paper No.: 2

Received: 22-03-2020

Revised: 18-05-2020

Accepted: 05-06-2020

\begin{abstract}
Osmo-dried apple pops and rings were prepared from "Golden Delicious" apples. The technology has been optimized for osmo-dried apple pops with a diameter of $28 \mathrm{~mm}$ and apple rings with a thickness of $0.5 \mathrm{~cm}$. In case of apple pops drying time of eight hour for sugar syrup and seven hours for honey syrup at $70^{\circ} \mathrm{B}$ osmotic sugar syrup at $50^{\circ} \mathrm{C}$ was optimized. The drying time of five hours has been optimized for osmo-dried apple rings with sugar and four hours for osmo-dried rings with honey. Honey osmo-dried apple pops and rings rated better in quality and sensory characteristics and with less water activity. The developed technology can be explored commercially at an industrial level for the production of quality osmo dried apple pops or apple rings.
\end{abstract}

Keywords: Apple, apple pops, apple rings, sugar, honey

The apple (Malus domestica) is one of the most important temperate fruits of Himachal Pradesh. It is cultivated in an area of 1,10,679 ha with a production of 7,77.126 MT and a productivity of 7.02 MT / ha (FAO, 2017). With high nutritional value, apple occupies an important place in food products and plays a vital role in people's economy. Apple contains many nutrients including vitamin $C$, potassium and fiber and is processed into a variety of products (Boyer and Liu (2004). Apple juice, pulp and concentrate are the main processed products on the market.

Fruits and vegetables contain high moisture content. Since the moisture content over 80 per cent, they are classified as highly perishable products. Keeping products fresh is the best way to maintain their nutritional value, but most preservation techniques require low temperatures, which are difficult to maintain throughout the supply chain (Shah et al. 2002). It is observed that over $20 \%$ of the world's perishable crops are dried to increase shelf life and promote food safety. Apples are subject to qualitative and quantitative losses after harvest and losses of up to $17 \%$ can occur during post-harvest and storage operations (Figiel, 2007). Poor quality and contamination of the product lead to the development of alternative drying technologies. Sun drying is a common method among those followed by growers to produce sun dried apple rings commonly known as Sakori, but the quality of sun dried apples is very poor. Nuts are beneficial to human health because they are rich sources of vitamins, minerals, antioxidants and especially fibers (including soluble fiber) due to their concentration during processing (Farzaneh et al. 2011).

How to cite this article: Sharma, B. and Vaidya, D. (2020). Standardization of Drying Time for Apple Pops and Apple Rings (Sugar, Honey). Int. J. Food Ferment. Technol., 10(1): 15-20.

Source of Support: None; Conflict of Interest: None 
Osmotic dehydration (sugar syrup) is a better drying method and is considered a preservation method that provides a high quality product and by removing water without phase change (Lenart, 1996). However, taking into account consumer health concerns, honey can be used as a sugar substitute in a hypertonic solution which can give a better osmosis dried product with good nutritional value.

Apple rings made with traditional technology are not getting better prices due to their look and taste. Therefore, developing new dried apple products using them in baked goods and confectionery can be a profitable creativity. Therefore, taking into account the demand for innovative products in the market and the enormous extent of the use of apples, the present study was conducted to develop consumerfriendly apple (sugar, honey) pops and rings and the results are reported here.

\section{MATERIALS AND METHODS}

\section{Raw materials}

The apples (Golden Delicious) harvested at their optimum ripeness were obtained from the local market. The raw material was purchased from the local market and the multifloral honey was purchased from the local farm, Dr. YS Parmar University of Horticulture and Forestry, Nauni, Solan, H.P and were used to conduct this study.

\section{Methods and procedure}

The soaking time for the pops and apple rings was initially optimized by selecting firm ripe fruit, followed by washing, peeling, and making pops and rings of different sizes. Apple pops $(28.08 \mathrm{~mm}$ in diameter) and apple rings ( $0.5 \mathrm{~cm}$ thickness) were prepared and blanched for 30 seconds. Blanched apple pops and rings were then osmotically dehydrated in hypertonic solution (sugar and honey) at $70^{\circ}$ Brix. Fruits of known weight were treated with different treatments. Osmosis was performed to optimize osmotic time in different time intervals $(1,2$, $3,4,5,6,7,8$ and $9 \mathrm{~h}$ ) in a ratio of 1 : 3 . Sizes that have osmosis have been standardized on the basis of the drying time. In addition, osmosic dried apple pops and rings were prepared, respectively.

\section{Physico-chemical analysis}

Physico-chemical characteristics of fresh apples, osmo dried apple pops and rings were accomplished using standard analytical techniques (Ting and Rouseff, 1986; AOAC, 1996 and Ranganna, 2009). The total soluble solids (TSS) content of fresh and processed products was determined using a manual refractometer and sugars were estimated by the Lane and Eynon method as detailed earlier (Ranganna, 2009). Acidity was determined by titrating aliquots against $0.1 \mathrm{~N} \mathrm{NaOH}$ to a pink end point using phenolphthalein as an indicator (Ranganna, 2009). Total phenols were extracted in $80 \%$ ethanol and calculated with the Folin-Ciocalteau reagent (AOAC, 1996). The antioxidant activity was analyzed by the free radical scavenging activity (Brand-William et al. 2005). The energy value of the developed products was measured in a bomb calorimeter (Toshiwal DT100 model), which is based on the principle that the amount of heat produced by burning the sample must be equal to the amount of heat absorbed by the whole (Kays and Barton, 2002). Furthermore, the non-enzymatic browning (NEB) was determined at $440 \mathrm{~nm}$ using $60 \%$ aqueous alcohol as a blank on the spectrometer (Spectronic-20).

\section{Statistical analysis}

Data obtained from the chemical characteristics of fresh and processed products were statistically analyzed following the Completely Random Design (CRD) detailed earlier (Cochran and Cox, 1992). The determinations were made in triplicate for each attribute.

\section{RESULTS AND DISCUSSION}

\section{Physico-chemical characteristics of apple}

Data on the physico-chemical characteristics of fresh apples are presented in Table 1. Length, breath, weight, specific gravity and firmness were observed as $65.80 \pm 0.10 \mathrm{~mm}, 68.66 \pm 0.02 \mathrm{~mm}, 124.07 \pm 0.02 \mathrm{~g}$, 
$10.60 \pm 0.20$ and $10.26 \pm 0.02 \mathrm{lb} / \mathrm{inch}^{2}$ respectively. (Sharma et al. 2000; Sharma et al. 2006) reported similar results in the Golden Delicious and Parlin's variety. Moisture content $(83.90 \pm 0.10 \%)$, ash content $(2.42 \pm 0.02 \%)$, titratable acidity $(0.40 \pm 0.01 \%)$, total soluble solids $\left(15.00 \pm 1.53^{\circ} \mathrm{B}\right)$, reducing sugars $(5.00 \pm$ $0.50 \%$ ), total sugars and non-reducing sugars of $8.33 \pm$ 0.02 and $3.33 \pm 0.01$ per cent were found,respectively. The results were comparable to those of Sharma et al. (1998). Ascorbic acid, total phenols and antioxidants were observed at $8.90 \pm 0.10 \mathrm{mg} / 100 \mathrm{~g}, 32.50 \pm 0.20 \mathrm{mg}$ $/ 100 \mathrm{~g}, 35.50 \pm 0.20$ percent, respectively. Sharma et al. (1998). Antioxidant activity and the phenol content $31.2 \mathrm{mg} / 100 \mathrm{~g}$ and $34.3 \mathrm{mg} / 100 \mathrm{~g}$ respectively have been found in "Granny smith" (Drogoudi and Pantelidis, 2011). Crude fibers were found between 2.00-3.00\%. Abdualrahman et al. (2015) reported similar results of $1.64 \pm 0.01 \%$ of crude fiber in apples, while a water activity of $1.00 \pm 0.50$ was observed.

Table 1: Physico- chemical characteristics of apple

\begin{tabular}{ll}
\hline Parameter & $\begin{array}{l}\text { Observations } \\
\text { (Mean } \pm \text { SE) }\end{array}$ \\
\hline Length $(\mathrm{mm})$ & $65.80 \pm 0.10$ \\
Breath $(\mathrm{mm})$ & $68.66 \pm 0.02$ \\
Weight $(\mathrm{g})$ & $124.07 \pm 0.02$ \\
Specific gravity & $0.98 \pm 0.01$ \\
Firmness (lbs)/inch $\left.{ }^{2}\right)$ & $10.26 \pm 0.02$ \\
Moisture content $(\%)$ & $83.90 \pm 0.10$ \\
Ash content $(\%)$ & $2.42 \pm 0.02$ \\
Titratable acidity $(\%)$ & $0.40 \pm 0.01$ \\
Total soluble solids $\left({ }^{\circ} \mathrm{B}\right)$ & $15.00 \pm 1.53$ \\
Reducing sugars $(\%)$ & $5.00 \pm 0.50$ \\
Non reducing sugar $(\%)$ & $3.16 \pm 0.02$ \\
Total sugars $(\%)$ & $8.33 \pm 0.02$ \\
Crude fiber $(\%)$ & $3.00 \pm 0.50$ \\
Ascorbic acid $(\mathrm{mg} / 100 \mathrm{~g})$ & $8.90 \pm 0.10$ \\
Phenols $(\mathrm{mg} / 100 \mathrm{~g})$ & $32.50 \pm 0.20$ \\
Water activity $\left(a_{w}\right)$ & $1.00 \pm 0.50$ \\
Flavonoids $(\%)$ & $10.00 \pm 0.50$ \\
Antioxidants $(\%)$ & $35.50 \pm 0.20$ \\
Non-enzymatic Browning $(440 \mathrm{~nm})$ & $0.02 \pm 0.02$ \\
\hline &
\end{tabular}

\section{Physico-chemical characteristics of honey (Multifloral)}

Data on the physico-chemical characteristics of fresh honey are presented in Table 2. The total soluble solids of fresh honey were $70.00^{\circ} \mathrm{B}$, which was higher than the values observed by Lakhanpal (2010) but was lower than the observations of Kaushik et al. (1993). The free acid, lactone and total acid content in meq per $100 \mathrm{~g}$ were $3.60,0.98$ and 4.47 respectively were slightly higher as recorded by (Singh, 1994) and Kaushik et al. (1993). Total and non-reducing sugars recorded were respectively $65.34 \%$ and $5.74 \%$. Lakhanpal (2010), Mishra (1995) and (Phadke, 1967) recorded the total sugars and non-reducing sugars of different types of honey, which were close to the values recorded in the study. Fresh honey had a moisture content of 16.50 per cent with an ash content of 0.19 per cent. The observed fructose, glucose and their proportions were $(35.85,30.24,1.18 \%)$ respectively. The observed fructose and glucose content of honey was 35.85 and 30.24 per cent, which was within the same range observed by Poncini and Wimmer (1987) and Singh (1994).

Table 2: Physico-chemical characteristics of multifloral honey

\begin{tabular}{ll}
\hline Parameters & Honey \\
\hline Total soluble solids $\left({ }^{\circ} \mathrm{B}\right)$ & $70.00 \pm 1$ \\
Free acid (meq/100 g) & $3.60 \pm 0.2$ \\
Lactone (meq/100 g) & $0.98 \pm 0.01$ \\
Total acid (meq/100g) & $4.47 \pm 0.01$ \\
$\mathrm{pH}$ & $3.86 \pm 0.02$ \\
Reducing sugars (\%) & $59.30 \pm 0.1$ \\
Non-reducing sugars (\%) & $5.74 \pm 0.01$ \\
Total sugars (\%) & $65.34 \pm 0.01$ \\
Moisture (\%) & $16.5 \pm 0.2$ \\
Total solids (\%) & $83.5 \pm 0.1$ \\
Ash (\%) & $0.19 \pm 0.01$ \\
Fructose (\%) & $35.85 \pm 0.01$ \\
Glucose (\%) & $30.24 \pm 0.01$ \\
Glucose: Fructose ratio & $1.18 \pm 0.01$ \\
Diastase Number (DN) & $20.50 \pm 0.1$ \\
Total phenols (mg/100g) & $65.45 \pm 0.02$ \\
HMF (mg/kg) & $9.35 \pm 0.01$ \\
\hline
\end{tabular}


The observed HMF content was $9.35 \mathrm{mg} / \mathrm{kg}$ lower than the values recorded by Lakhanpal (2010), Bulut and Kilic (2009). However, the number of diastases recorded was higher than the values observed by (Hebbar et al. 2003) and (Simpson et al. 1968). Ivanov (1973) reported a diastasis number of 24.8, although Nair (1983) and Phadke et al. (1970) found that the number of diastases ranged between 0-2.5 and 0-12.5, respectively.

Standardization of drying time for osmo-dried apple pops and apple rings (Sugar and Honey)

The data presented in Fig. 1 show the drying time of osmosis dried apple pops (sugar and honey). For apple pops dipped in sugar, there was a weight loss of $13.59 \%$ and $17.42 \%$ for apple pops dipped in honey after one hour, while after two hours there was almost the $50 \%$ weight loss, which is $49.6 \%$ for sugar-dipped pops and $53.2 \%$ in apple pops dipped in honey. There was no weight loss after eight hours for sugar-dipped apple pops and seven hours for honey-dipped apple pops, no further reduction in pops weight.

The data presented in Fig. 2 shows the drying time for osmo-dried apple rings (sugar and honey). In case of sugar dipped apple rings there was 32.25 per cent weight loss and 35.35 per cent in honey dipped apple rings after one hour while after two hour there was 54.83 per cent weight loss in sugar dipped rings and 58.42 per cent in honey dipped apple rings. After five hours in case of sugar dipped

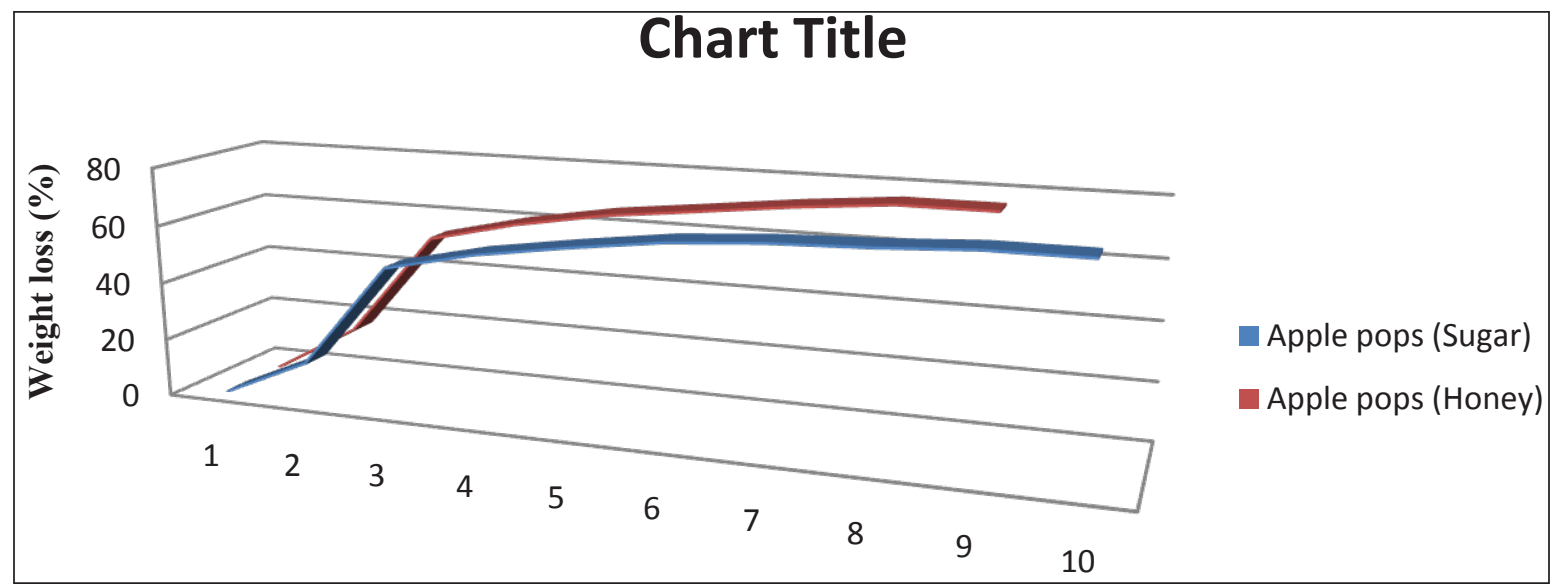

Fig. 1: Standardization drying time for apple pops (Sugar) and (Honey)

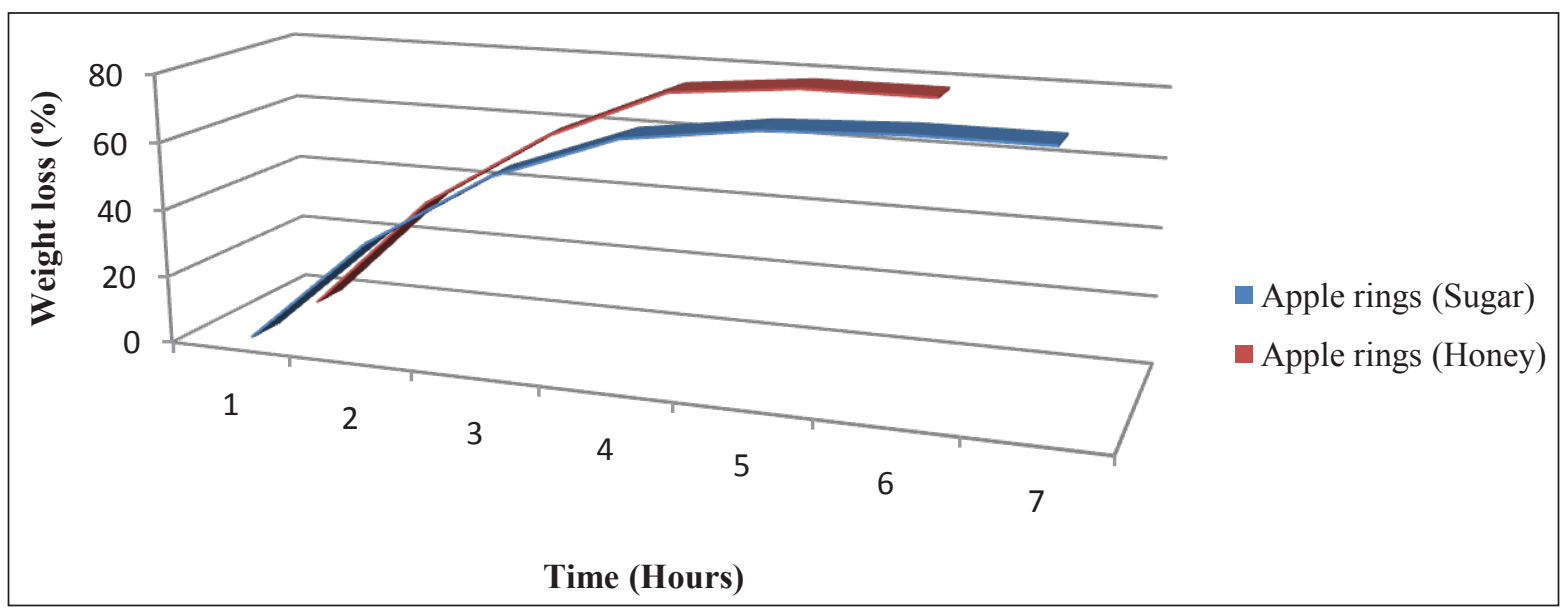

Fig. 2: Standardization of drying time for apple rings (Sugar) and (Honey) 
apple rings (75.30 \%) and four hours in case of honey dipped apple rings $(78.03 \%)$ there was no further reduction in weight of rings. The moisture content in the apple tissue decreases exponentially with time from $5.54 \mathrm{~g} \mathrm{H}_{2} \mathrm{O} / \mathrm{g}$ dry solids to $1.59 \mathrm{gH}_{2} \mathrm{O} / \mathrm{g}$ dry solids after 24 hours (Derossi et al. 2008). Seiiedlou et al. (2010) observed that moisture content of samples decreases exponentially with the drying time and increased with increasing the drying air temperature and velocity. Similar results were observed by Figiel, (2007) in apple cubes. It has been concluded that 28 $\mathrm{mm}$ diameter for apple pops with osmo dipping time of three hours in case of sugar and four hours in case of honey at $50^{\circ} \mathrm{C}$ dried in eight hours and seven hours respectively. Apple rings of $0.5 \mathrm{~cm}$ thickness with osmo-dipping time of three and four hours in sugar and honey respectively at $50^{\circ} \mathrm{C}$ dried in five hours in sugar and four hours in honey.

\section{CONCLUSION}

It can be concluded that apples can be used for the preparation of osmosis dried apple pops and rings. These osmo-dried products can also be used for the development of baked goods which are the newest products on the market. Furthermore, the use of honey for osmotic dehydration improves the nutritional quality of the products developed. Moreover, the drying time for both pops and rings with honey and sugar as hypertonic solution is also standardized. It is also concluded that honey osmo-dried apple pops and rings performed better in quality and sensory characteristics and with less water activity.

\section{REFERENCES}

Abdualrahman, M.A.Y. 2015. Comparative study between local and imported apple (Malus domestica) fruits and their use in juice production. Sci. Int., 3: 69-72.

FAO. 2017. FAO statistical database. Food and Agriculture Organization. http:// www.fao.org.

AOAC. 1996. Official Analytical Chemist Association Official Methods of Analysis, Hortwits W (ed). Official Anal Assoc. Chemicals, Washington, D.C. USA

Boyer, J. and Liu, R.H. 2004. Apple phyto-chemicals and their health benefits. Nutr. J., 3: 5 .
Brand-Williams, W. Cuvelier, M.E. and Berset, C. 1995. Use of a free radical method to evaluate antioxidant activity. Lebensmittel-Wissenschaft und Technologie, 28: 25-30.

Bulut, L. and Kilic, M. 2009. Kinetics of hydroxymethylfurfural accumulation and color change in honey during storage in relation to moisture content. J. Food Process Preserv., 33: 2232.

Cochran, W.G. and Cox, G.M. 1992. Experimental designs (2 ${ }^{\text {nd }}$ edn.). New York: Wiley. ISBN; 978-0-471-54567-5.

Derossi, A., De, Pilli, T., Severini, C. and Mc, Carthy., M.J. 2008. Mass transfer during osmotic dehydration of apples. J. Food Eng., 86: 519-528.

Drogoudi, P.D. and Pantelidis, G. 2011. Effect of position on the canopy and of harvest time on the physico-chemical and antioxidant properties of the fruit in different apple cultivars. Scientia Horticulturae, 129: 752-760.

Farzaneh, P., Fatemian, H., Hosseini, E., Asadi, G.H. and Darvish, F.A. 2011. Comparative study on drying and coating of osmosis treated apple rings. Int. J. Agric. Sci. Res., 2: 57-66.

Figiel, A. 2007. Dehydration of apples using a combination of convection and vacuum microwave drying. Pol. J. Food Nutr. Sci., pp. 131-135.

Hebbar, H.U., Nandini, K.E., Lakshmi, M.C. and Subramanian, R. 2003. Processing of honey by microwave and infrared heat and its quality. Food Science Res. Technique, 9: 49-53.

Invanov, T.S. 1973. Diastase activity and 5-hydroxymethyl furfural content of honey. Zhivotnovudni Nauki, 10: 117-122.

Kaushik, R., Joshi, V.K. and Gupta, J.K. 1993. Total soluble solids, acidity, $\mathrm{pH}$ and number of standard plates in Indian honey affected by different processing and storage conditions. J. Food Sci. Tech., 30: 442-443.

Kays, S.E. and Barton, F.E. 2002. Rapid prediction of gross energy and usable energy in cereal-based food products using near-infrared reflectance spectroscopy. J. de Agric. Food Chem., 50: 284-289.

Lakhanpal, P. and Vaidya, D. 2015. Development and evaluation of honey-based mango nectar. J. Food Sci. Tech., 52: 1730-1735.

Lenart, A. 1996. Osmo-convective frying of fruit and vegetables: technology and application. Dry. Tech., 14: 391341.

Mishra, R.C. 1995. Bees and their management in India. ICAR, New Delhi, pp. 168.

Nair, K.S. 1983. Physico-chemical characteristics of rubber honey in India. Proceedings of the Second International Conference on Beekeeping in Tropical Climates, New Delhi, pp. 674-684.

Phadke, R.P., Nair, K.S. and Nandedkar, U. 1970. Indian honey studies. IV. Minor components. Indian Bee J., 32: 29-35. 
Phadke, R.P. 1967. Studies on Indian honey. Approximate composition and physico-chemical characteristics of Mahabaleshwarunifloral honeys. Indian Bee J., 29: 33-36.

Poncini, L. and Wimmer, F.L. 1987. The composition of some Fijian honeys. Beekeeping Extract, 32: 281.

Ranganna, S. 2009. Manual of analysis and quality control of horticultural products. $4^{\text {th }}$ edition, Tata McGraw Hill, New Delhi, pp. 1112.

Seiiedlou, S., Ghasemzadeh, H.R., Hamdami, N., Talati, F. and Moghaddam, M. 2010. Convective drying of the apple: mathematical modeling and determination of some quality parameters. Int. J. Agri. Bio., 12: 171-178.

Shah, N., Khan, M., Kasi, A. and Khair, M. 2002. Post-harvest losses and cold storage in Baluchistan apple. Asian J. Plant Sci., 1: 65-66.

Sharma, K.D., Sethi, V. and Maini, S.B. 2000. Effect of pretreatment and package on chemical and sensory characteristics of dried apple. Indian Food Packers, pp. 52-59.
Sharma, K.D., Alkesh and Kaushal, B.B.L. 2006. Evaluation of apple cultivars for dehydration. J. Food Tech., 43: 177-181.

Sharma, K.D., Sethi, V. and Maini, S.B. 1998. Changes in the quality of osmo-vac dried apple slices during storage. J. Sci. Ind. Res., 57: 393-398.

Simpson, J., Riedel, I.B. and Wilding, N. 1968. Invertase in the hypopharyngeal glands of the bee. J. Api. Res., 7: 29-36.

Singh, B. 1994. Studies on the physico-chemical characteristics of honey from important floral sources in Punjab. M.Sc. PAU thesis, Ludhiana.

Ting, S.V. and Rouseff, R.L. 1986. Citrus and its products: analysis and technology. Marcel Dekker, Inc., New Delhi, pp. 293. 